UDC 332.363

\title{
LAND INVENTORY AS A PREREQUISITE FOR EFFECTIVE LAND RESOURCE MANAGEMENT
}

Butenko E.V. Candidate of Economic Sciences, Associate Professor E-mail:evg_cat@ukr.net

Danshova A.V. master of 2 years of study E-mail:danshova.97@gmail.com

Yurchenko I.V. master of 2 years of study E-mail:yaremchukiryna166@gmail.com

National University of Life and Environmental Sciences of Ukraine

Abstract. This article discusses the issue of land inventory. It is noted that land inventory is one of the main means of ensuring effective land management. In addition, the problems that can be solved by land inventory for the effective management of land resources are demonstrated. It is stated that land inventory is a certain tool for land policy through land monitoring, which allows to identify inconsistencies in land use and land condition.

It was revealed that the main purpose of the inventory is to create an information basis for maintaining the state land cadastre, control over land use and registration of land plots. It is considered that the clarification of the legislative regulation of land inventory will contribute to the quality of state management of land resources of Ukraine. The article explored two objects. The current state of use of their lands is analyzed. As a result, ways to solve the problems that exist in the use of land of the State Enterprise «Experimental Farm «Victory» Volyn State Agricultural Research Station of the National Academy of Agrarian Sciences of Ukraine» and the Experimental Station of Tobacco of the National Research Center «Institute of Agriculture of the National Academy of Agrarian Sciences of Ukraine».

Key words: land inventory, land resources management, State Land Cadastre, land relations, State Register of Real Property Rights, land use. 
Urgency of problems. At this stage of development of land relations, land inventory is a tool to improve the effective management of land resources. As you know, today in Ukraine there is a problem of land inventory, because the territory of Ukraine is not fully inventoried.

The information that most state institutions and enterprises of NAAS own land requires an analysis of the state of use with the entry of information in the State Land Cadastre. These issues can be addressed through an inventory of these lands.

Carrying out a high-quality land inventory was conditioned by the decentralization reform in the country, which was accompanied by the formation of new administrative-territorial units - united territorial communities. According to the State Geocadastre, about 5 million hectares of state-owned land are currently missing from the state's balance sheet and it is unknown who owns the land now. In order to solve this problem, it is necessary to conduct an inventory and digitize paper data for the period 2002-2013, this will create an information base for effective land management.

Analysis of recent research and publications. As a result of the analysis, works on land inventory in Ukraine are regulated by regulatory and legal support [1, 2, 3, 4]. The works of scientists: J. Dorosh, O. Dorosh, M. Kalyuzhny, A. Martin and others were devoted to land inventory to improve the effective management of land resources. The issue of inventory of lands of settlements and lands of non-agricultural purposes outside them was studied by O. Dorosh [5]. A. Martin [6] studied the problems of organizational and legal support of land inventory. Methodical approaches to the inventory of agricultural lands were described in the works of $\mathrm{J}$. Dorosh and M. Kalyuzhny [7]. However, the issue of land inventory is relevant in modern conditions and requires further research.

The purpose of the study is a scientific analysis of land inventory work as a prerequisite for effective management in terms of reforming land relations.

\section{Presenting main material.}

«Land inventory is carried out in order to establish the location of land management facilities, their boundaries, size, legal status, identification of land that is not used, used irrationally or not for its intended purpose, detection and 
conservation of degraded agricultural land and contaminated land, establishing quantitative and qualitative characteristics of lands required for the maintenance of the State Land Cadastre, the implementation of state control over the use and protection of lands and the adoption of appropriate decisions on their basis by the executive authorities and local governments» in accordance with the Resolution of the Cabinet of Ministers of Ukraine № 476 of June 5, 2019 «On approval of the Procedure for conducting an inventory of lands and recognizing as invalid some resolutions of the Cabinet of Ministers of Ukraine» [8]. Land inventory is needed to assess the quantitative and qualitative composition of land in the district, region and territory of the whole country. In addition, effective land management is ensured through inventory. For example, local governments will not be able to illegally dispose of land or allocate land for other purposes. Land inventory is also important in the following cases: identification and conservation of unproductive land, contaminated land, degraded agricultural land, control over land protection, land management.

To date, the State Service of Ukraine for Geodesy, Cartography and Cadastre has conducted an inventory of state-owned agricultural land with a total area of 1018.9 thousand hectares:

- carrying out topographic and geodetic works on land plots - 1075.3 thousand hectares;

- state registration of land plots in SLC - 964.4 thousand hectares;

- approval of technical documentation on land management for land inventory 826.8 thousand hectares [9].

In the territory of Rivne and Kherson oblasts a measure on inventory of stateowned agricultural lands was fully carried out. In addition, topographic and geodetic works have been completed in Zaporizhia and Poltava regions.

As we can see, a very small part of Ukraine's land is inventoried. This is due to insufficient funding for inventory work.

In order to demonstrate the importance of inventory, it is necessary to analyze the effective use of land in certain areas. The objects of the study are 2 objects of the National Academy of Agrarian Sciences of Ukraine: State Enterprise «Experimental 
Farm «Victory» Volyn State Agricultural Research Station of the National Academy of Agrarian Sciences of Ukraine» and Experimental Station of Tobacco of the National Research Center «Institute of Agriculture of the National Academy of Agrarian Sciences of Ukraine». During the analysis it was found that the total area of land use of the State Enterprise «Experimental Farm «Victory» Volyn State Agricultural Research Station of the National Academy of Agrarian Sciences of Ukraine» is 2019.55 hectares. While the total land area of the Experimental Station of Tobacco of the National Research Center «Institute of Agriculture of the National Academy of Agrarian Sciences of Ukraine» is 284.0172 hectares.

During the study it was found that the total area of land plots of SE EF «Victory» Volyn SARS NAAS, which are privately owned by citizens and land within land use, which are not registered in the State Land Cadastre is 479.5756 hectares. The area of land plots in communal ownership is 919.7844 hectares. As a result of the analysis of the current state of land use of SE EF «Victory» Volyn SARS NAAS revealed that within the land use registered land plots in the State Land Cadastre with a total area of 1523.6852. It is established that in the State Land Cadastre the area of registered land plots is 495.8648 ha less than the area of land use, certified by a state act on the right of permanent land ownership (Table 1).

Table 1. Analysis of the difference in land use of SE EF «Victory» Volyn SARS NAAS according to the state act on the right of permanent land ownership and data of the State Land Cadastre

\begin{tabular}{|c|c|c|c|c|}
\hline $\begin{array}{c}\text { № } \\
\text { in/ } \\
\text { o }\end{array}$ & Name of the farm & $\begin{array}{c}\text { Area } \\
\text { according to } \\
\text { the state act, } \\
\text { ha }\end{array}$ & $\begin{array}{c}\text { Area } \\
\text { according to } \\
\text { SLC, ha }\end{array}$ & $\begin{array}{c}\text { The } \\
\text { difference } \\
\text { in area, ha }\end{array}$ \\
\hline 1 & $\begin{array}{c}\text { SE EF «Victory» Volyn SARS } \\
\text { NAAS }\end{array}$ & 2019,55 & 1523,6852 & $-495,8648$ \\
\hline \multicolumn{2}{|c|}{ Totally, ha } & 2019,55 & 1523,6852 & $-495,8648$ \\
\hline
\end{tabular}

In turn, during the analysis of the current state of land use EST NRC «IA NAAS» found that within the land use, registered land in the State Land Cadastre with a total area of 275.1106 hectares. 
Thus, it was found that in the State Land Cadastre the area of registered land plots is 8.9066 ha less than the area of land use certified by state acts on the right of permanent land use (Table 2).

Table 2. Analysis of the difference of land use areas of EST NRC «IA NAAS» according to the state act on the right of permanent land ownership and data of the State Land Cadastre

\begin{tabular}{|c|c|c|c|c|}
\hline $\begin{array}{c}\text { № } \\
\text { in/ } \\
\text { o }\end{array}$ & Name of the farm & $\begin{array}{c}\text { Area } \\
\text { according to } \\
\text { the state act, } \\
\text { ha }\end{array}$ & $\begin{array}{c}\text { Area } \\
\text { according to } \\
\text { SLC, ha }\end{array}$ & $\begin{array}{c}\text { The } \\
\text { difference } \\
\text { in area, ha }\end{array}$ \\
\hline 1 & EST NRC «IA NAAS» & 284,0172 & 275,1106 & $-8,9066$ \\
\hline \multicolumn{2}{|c|}{ Totally, ha } & 284,0172 & 275,1106 & $-8,9066$ \\
\hline
\end{tabular}

It should be noted that as a result of discrepancies in the accounted areas of lands of SE «Experimental Farm «Victory» Volyn State Agricultural Research Station NAAS of Ukraine» and Experimental Station of Tobacco of the National Research Center «Institute of Agriculture NAAS of Ukraine», which are currently not accounted for lands of these farms, the rate of return and there are prerequisites for raider capture of these lands.

\section{Conclusions and suggestions.}

Thus, land inventory as a prerequisite for effective land management contributes to the filling of information about land and the state of their use. After the analysis of these farms, lands that were not registered in the State Land Cadastre were identified.

The identified problems with the mismatch of areas determine the priority of conducting an inventory of lands of state-owned enterprises and entering relevant information into the database.

The implementation of these principles will avoid the risks of: unearned income due to the use of these plots; probabilities of raider seizure, because it is much easier and simpler to take over lands that are not registered; non-payment of land tax to local budgets and improve the efficiency of land management. 
1. Zemelnyi kodeks Ukrainy. Rezhym dostupu https://zakon.rada.gov.ua/laws/ show/2768-142.

2. The Verkhovna Rada of Ukraine (2003). The Law of Ukraine «On land management». Available at: http://zakon.rada.gov.ua/ laws/show/858-15.

3. Cabinet of Ministers of Ukraine (2012). Resolution of the Cabinet of Ministers of Ukraine № 1051 «On Approval of the Procedure for the State Land Cadastre». Available at: https://zakon.rada.gov.ua/laws/ show/1051-2012-\%D0\%BF.

4. The Verkhovna Rada of Ukraine (2011). The Law of Ukraine «On State land cadastre». Available at: http://zakon.rada.gov.ua/ laws/show/3613-17\#n369.

5. Dorosh, O.S. (2015), «Inventaryzatsiia zemel: metodychni pidkhody do yii provedennia», Ahrosvit, vol.11, pp. 24-30, available at: http://nbuv.gov.ua/UJRN/agrosvit_2015_11_5.

6. Martyn, A.G. (2011), «Inventory of land: how to implement it in modern terms», Zemelniy soyuz Ukrainy, available at: http://zsu.org.ua/index.-php/andrijmartin/91-2011-05-27-14-48-38(Accessed 15 May 2015).

7. Kalyuzhniy, M.N. and Dorosh, Y.M. (2011), «Scientificmethodical bases inventory of agricultural land», Zemlevporyadniy visnik, vol.6, pp. 29-31.

8. Postanova Kabinetu Ministriv Ukrainy «Pro zatverdzhennia Poriadku provedennia inventaryzatsii zemel ta vyznannia takymy, shcho vtratyly chynnist, deiakykh postanov Kabinetu Ministriv Ukrainy» vid 05.06.2019 r. № 476. Available at: https://zakon. rada.gov.ua/laws/show/476-2019-\%D0\%BF.

9. Derzhheokadastr shchodo provedennia inventaryzatsii zemel silskohospodarskoho pryznachennia derzhavnoi vlasnosti. Available at: https://www.kmu.gov.ua/news/derzhgeokadastr-shchodo-provedennyainventarizaciyi-zemel-silskogospodarskogo11-priznachennya-derzhavnoyi-vlasnosti.

Е.Бутенко, А.Даньшова, И.Юрченко

ИНВЕНТАРИЗАЦИЯ ЗЕМЕЛЬ КАК ПРЕДПОСЫЛКА ЭФФЕКТИВНОГО УПРАВЛЕНИЯ ЗЕМЕЛЬНЫМИ РЕСУРСАМИ

Аннотация. В данной статье рассмотрены вопросы инвентаризации земель. Отмечено, что инвентаризация земель является одним из главных 
средств обеспечения эффективного управления земельными ресурсами. Кроме того, продемонстрированы проблемы, которые позволяет решить инвентаризация земель для эффективного управления земельными ресурсами. Констатировано, что инвентаризация земель выступает определенным средством для проведения земельной политики путем мониторинга земель, который и позволяет вылвить несоответствия в использовании земельньх участков и состояние земель.

Выявлено, что основной цุелью проведения инвентаризацุии является создание информационной основы для ведения государственного земельного кадастра, проведение контроля за использованием земель и регистрация земельных участков. Рассмотрены, что уточнение законодательного регулирования инвентаризации земель будет способствовать качества государственного управления земельныли ресурсами Украины. В статье были исследованы два объекта. Проанализировано современное состояние использования земель. В итоге были предложены пути решения проблем, которые существуют в использовании земель Государственного предприятия «Oпьтное хозяйство« Победа »Вольнской государственной сельскохозяйственной опьтной станции Национальной академии аграрньх наук Украины» и Исследовательской станцуии табаководства Нацчионального научного центра «Институт земледелия Нацчиональной академии аграрных наук Украиньl».

Ключевые слова: инвентаризацияя земель, управление земельными ресурсами, Государственный земельный кадастр, земельные отномения, Государственный реестр вещзных прав на недвижимое имущество, землепользования.

\section{С.Бутенко, А.Даньшова, І.Юрченко}

ІНВЕНТАРИЗАЦІЯ ЗЕМЕЛЬ ЯК ПЕРЕДУМОВА ЕФЕКТИВНОГО УПРАВЛІННЯ ЗЕМЕЛЬНИМИ РЕСУРСАМИ

Анотація. У даній статті розглянуто питання інвентаризації земель. Відзначено, щ⿻о інвентаризачія земель є одним із головних засобів забезпечення 
ефективного управління земельними ресурсами. Крім того, продемонстровані проблеми, які дозволяе вирішити інвентаризація земель задля ефективного управління земельними ресурсами. Констатовано, що інвентаризація земель виступає певним засобом для проведення земельної політики шляхом моніторингу земель, який $і$ дозволяє виявити невідповідності у використанні земельних ділянок та стан земель.

Виявлено, щуо основною метою проведення інвентаризації є створення інформаційної основи для ведення державного земельного кадастру, проведення контролю за використанням земель та реєстрація земельних ділянок. Розглянуто, що уточнення законодавчого регулювання інвентаризації земель сприятиме якості державного управління земельними ресурсами Украӥни. У статті було досліджено два об'єкта. Проаналізовано сучасний стан використання їх земель. У підсумку було запропоновано шляхи вирішення проблем, які існують у використанні земель Державного підприємства «Дослідне господарство «Перемога» Волинської державної сільськогосподарської дослідної станиї Наџіональної академії аграрних наук України» та Дослідної станиії тютюнниџтва Національного наукового цฺентру «Інститут землеробства Наџіональної академії аграрних наук України».

Ключові слова: інвентаризація земель, управління земельними ресурсами, Державний земельний кадастр, земельні відносини, Державний реєстр речових прав на нерухоме майно, землекористування. 